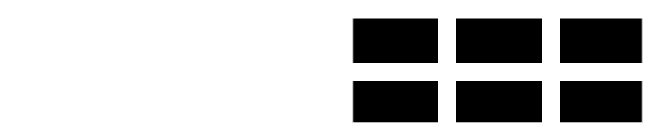

THE WILLIAM DAVIDSON INSTITUTE AT THE UNIVERSITY OF MICHIGAN BUSINESS SCHOOL

Job Search Behavior of Unemployed in Russia

\author{
By: Natalia Smirnova
}

William Davidson Institute Working Paper Number 629

November 2003 


\title{
Job Search Behavior of Unemployed in Russia ${ }^{1}$
}

\author{
Natalia V. Smirnova ${ }^{2}$
}

August 2003

\begin{abstract}
This paper explores the determinants of job search behavior, search intensity and choices of search methods of the unemployed workers in transitional Russia. We use pooled data from rounds 5-9 of the Russia Longitudinal Monitoring Survey (RLMS) to estimate the effects of socio-economic factors on the choices workers make while looking for a job.

The results show that women are significantly less likely than men to engage in job search, they lag significantly behind men in search intensity, and significantly differ from men in their search strategies. Job search behavior of workers living in metropolitan areas of Moscow and St. Petersburg varies substantially from the behavior of workers living in other regions of Russia. The most frequently used search strategy in Russia, as in other countries, is contacting friends and relatives for job leads.
\end{abstract}

JEL Code: J64, P23

Key Words: Russia, Transition, Job Search, Search Intensity, logit

\footnotetext{
1 This paper was written while the author was a Visiting Researcher at the Bank of Finland Institute for Economies in Transition (BOFIT), Helsinki, Finland, May-August, 2003. It benefited from the discussions at the BOFIT seminars and workshops during the summer of 2003. The author is thankful to Rita Asplund, Pekka Ilmakunnas, Erkki Koskela, Roope Uusitalo, Andrea Weber and seminars' participants for useful comments and to BOFIT for providing excellent research facilities. The usual disclaimer applies.

2 Department of Economics, University of Connecticut, Storrs, CT, USA, and Bank of Finland Institute for Economies in Transition (BOFIT), Helsinki, Finland. Natalia.Smirnova@UConn.edu.
} 


\section{Non-Technical Summary}

Since the beginning of economic transformation in Russia in 1991 the process of job search has become an integral part of labor market activity. Even though, the majority of workers use personal contacts as their primary job search method, other forms of matching job vacancies and job seekers start to develop.

This paper explores the determinants of job search behavior, search intensity and a choice of search methods of the unemployed workers in transitional Russia. The importance of the analysis of search behavior lies in uncovering the mechanisms underlying the duration and rate of unemployment. From the economic policy perspective the analysis of search methods suggests the ways of improving the means by which employees are matched with jobs.

We use the pooled data for rounds 5-9 of the Russia Longitudinal Monitoring Survey (RLMS) to sequentially estimate three equations. Engagement of job search equation shows the propensity to search for a job by different socio-economic groups of individuals. The results of binomial logit procedure show that workers in the prime work age, with a completed secondary and college education, with children of the pre-school age, or living in the metropolitan areas of Moscow and St. Petersburg have a higher propensity to search for a job. On the other hand, such factors as being female or belonging to the older age group reduces the propensity to search. Additionally, labor market characteristics, such as wage arrears, increase search propensity.

Search intensity equation measures the effect of individual and household factors on the number of methods used during search. On average, Russian unemployed searcher 
uses 2 methods to find a job. The ordered logit estimation revealed that women and people with more experience search less intensely. However, workers with secondary or college education, or living in metropolitan areas of Moscow and St. Petersburg search for jobs more intensely.

Search method choice equation reveals the effects of individual and household characteristics on the likelihood of using a particular job search strategy. Multinomial logit was used to analyze these effects. The results show that women are more likely to apply to AGENCIES (state and private) than use other search strategies. People with more experience are more likely to use FIRMS (application directly to the enterprise and through advertisements) and AGENCIES instead of CONTACTS (relatives and friends) for their job leads. Residents of the metropolitan areas of Moscow and St. Petersburg are more likely to use CONTACTS and FIRMS instead of AGENCIES.

The fact that overall search intensity, as well as its allocation across methods, are chosen differently by different individuals suggests that the specifics of search behavior are the important part of functioning of the labor market in Russia, as the model suggests they should be. More research is needed, however, to advance our understanding of the search behavior of unemployed workers in Russia. 


\section{Natalia V. Smirnova}

\section{Job Search Behavior of Unemployed in Russia}

\section{Introduction}

Since the beginning of economic transformation in Russia in 1991 the process of job search has become an integral part of labor market activity. Even though, the majority of workers use personal contacts as their primary job search method, other forms of matching job vacancies and job seekers start to develop. For example, between 2001 and 2002 applications to commercial employment agencies had almost doubled, and almost tripled between 2000 and $2002^{3}$. New methods of job search, such as Internet use, start to emerge. ${ }^{4}$

This paper explores the determinants of job search behavior, search intensity and a choice of search methods of the unemployed workers in transitional Russia. The importance of the analysis of search behavior lies in uncovering the mechanisms underlying the duration and rate of unemployment. From the economic policy perspective the analysis of search methods suggests the ways of improving the means by which employees are matched with jobs.

The paper is organized as follows: Section 2 motivates the paper by offering a short description of labor market development in Russia in 1993-2002 and a summary of empirical literature; Section 3 describes the data; Section 4 identifies the theoretical model; Section 5 describes the statistical model and the estimation procedure; Section 6 discusses empirical results; Section 7 presents the conclusions.

\footnotetext{
3 International Monetary Fund. 2003. IMF Country Report No.03/145. Russian Federation: Statistical Appendix: p.17.

4 Roshchin and Markova (2003).
} 


\section{Motivation}

\subsection{Labor Market Development in Transitional Russia}

In order to put the Russian labor market development in global perspective, Table A.1.1. in Appendix 1 compares labor market indicators among European Union countries (EU-15), Acceding into EU in 2004 countries (ACC-10), United States and Russian Federation. The employment rate in Russia for persons 15-64 years of age stands at $58.6 \%$, which is smaller than for the EU and the US, but larger than for ACC. Unemployment rate in Russia (8.9\%) is higher than in the EU and the US, but lower than in ACC. The unemployment duration is similar to EU countries, where the majority of people are unemployed less than 6 months ( $45 \%$ in Russia and $42 \%$ in EU). The proportion of people who are unemployed for more than a year in Russia is similar to EU as well (36\% in Russia and $40 \%$ in EU). This pattern is quite different from the USA (where $81 \%$ of unemployed find jobs within first 6 months of unemployment) and from the ACC (where the majority of people are unemployed for more than 12 months).

Comparing Russia with other transition countries, the common features of labor market transformation should be identified. The stylized facts of such transformation are: (1) Lower-educated single individuals, women and young people are more likely to become unemployed. The same groups, except young people, tend to stay in unemployment pool longer. (2) Married women are worse off in terms of job loss and length of unemployment than single women. (3) Returns to a year of education have increased during the transition years. But gender gap in education premia has narrowed. (4) Returns to experience have declined. (5) Regional asymmetries persist. 
Aside from these common features the labor market adjustment paths in the transitional arena are quite different. Boeri and Terrell (2002) conclude that Central and Eastern European (CEE) countries have experienced significant employment adjustment, rapid structural change, high and long-term unemployment (except Czech Republic). Countries of former Soviet Union (FSU) have had low responsiveness of employment to output changes, strong and persistent wage decline, slower structural change, gradual build-up of unemployment (except Estonia) and large turn-over rate. Special feature of the Russian labor market has been accumulation of wage arrears (unpaid wages or outstanding pay), which allowed wages but not employment to adjust downwards. This prompted to depict Russian labor market as a "neoclassical dream" or "the example of flexible labor market" ${ }^{\text {"5 }}$. Overall, wages adjusted more in the FSU countries and employment adjusted more in CEE countries, which contributed to the faster structural change in Eastern Europe.

The main focus of this study is the process of job search of unemployed in Russia. Table A1.2. in Appendix 1 presents the distribution of unemployed by search methods use. Contacting friends, relatives and acquaintances is the most frequently used search method through the years of 1993-2002. Its use had steadily grown from $37 \%$ of searchers utilizing it in 1993 to $60 \%$ in 2002. Applications to state employment services and direct contacts of employers compete for the second place in frequency of use. In 1993, 1999, and 2000 applications directly to firms were higher than application to the state employment service. In other years, state employment service was more frequently utilized. Placing ads and responding to ads had grown steadily and substantially from $13 \%$ in 1993 to $24 \%$ in 2002 . Application to commercial, or private, employment

5 Layard and Richter (1995). 
services is the least utilized method of finding a job. However, its use had gained momentum in 1993 - 1996. Then it declined in 1997 and 1999, and subsequently increased three-fold from 2000 to 2002, and two-fold from 2001 to 2002 .

The sustained high level of unemployment and substantial level of long-term unemployment duration in Russia calls for inquiries into the reasons of such phenomena. Job search behavior is one of the factors that influence the duration and level of unemployment in the economy. Thus, the study of the determinants of choices that people make while searching and the factors influencing job search provide valuable insights in the "matching" function of the labor market. In the next section we summarize the theoretical underpinnings and practical applications of the job search literature, which motivate the empirical part of this study.

\subsection{Literature Overview}

The developments in the literature on job search are summarized by Mortensen $(1986,1999)$. Our particular interest lies in the aspect of "matching approach" to labor market analysis, where the goal is to explain worker and job flows and levels of unemployment within the rational forward looking agent paradigm. The success of job search process depends, among other things, on the intensities with which workers search for jobs and choices they make when searching. This paper is an application of the stationary job search model, where individuals choose search methods and search intensity in order to influence the arrival rate of job offers thereby maximizing their utility functions. 
This particular aspect of the search theory was empirically tested by the application to the labor markets of different countries. Holzer (1988), Blau and Robins (1990) examined the job search behavior of the unemployed in the United States. Gregg and Wadsworth (1996) studied the efficiency of search methods in the United Kingdom. Addison and Portugal (2001) assessed the effects of job finding methods on escape rates from unemployment and on earnings using Portuguese data. Weber and Mahringer (2002) compared the quality of job matches in terms of wages and job durations between different search methods in Austria. Osberg (1993) found a relationship between the probability of finding a job and the business cycle for employment services in Canada. Lindeboom et. al. (1994) ascertained large differences in the effectiveness of search channels for the Netherlands's labor market. Eriksson, Lilja and Torp (2002) evaluated the determinants of search intensity in Denmark, Finland and Norway.

For transition countries of Central and Eastern Europe (CEE) the duration of search (unemployment) and unemployment benefits systems' effect on duration are the main focus of the search literature. Ham, Svejnar and Terrell (1998) applied proportional hazard model to the Czech and Slovak labor markets. Vodopivec (1995) assessed the unemployment insurance effect on unemployment duration for Slovenia. Lubyova and Van Ours (1997) estimated the hazard function for Slovak Republic. Hinnosaar (2003) examined the dependence of the duration of unemployment spell on reservation wage and job search intensity in Estonia.

Russian labor market transformation has received attention in the economic literature as well. Foley (1997) examined the duration of unemployment and labor force mobility between labor market states. Sabirianova (2000) analyzed the occupational 
mobility of the labor force. Earle and Sabirianova (2002) explain effects and consequences of wage arrears. Stillman (2001) assessed the unemployment rates. Gimpelson and Lippoldt (1999) evaluated job creation in the private sector. Geishecker and Haisken-DeNew (2002) studied job creation and job destruction and inter-industry wage structure. Grogan and Van den Berg (1999) estimated the duration models for four sub-groups of the unemployed and marginally employed. Denisova $(2003,2002)$ and Schüle (2003) evaluated management practices of the Federal Employment Services.

Up to date, only Roshchin and Markova (2003) performed a rigorous analysis of the search strategies used in the Russian labor market. Their research focuses on time intensity and cost intensity of the search methods, unemployment duration and "learning effect" dependence of the job search process. The study separates the behavior of the unemployed and "on-the-job-search" of the employed. However, the specific choices that unemployed individuals make in their decision whether to search for a job, how intensely to search, and what specific methods to use have not been addressed in the literature on Russian labor market. Nevertheless, these choices are extremely important in that they influence the probability of obtaining an offer, and thus, the probability of employment.

This paper responds to the urgency in filling the gap in the empirical literature with respect to the in-depth study of labor supply in Russia. To this end, our study analyzes job search behavior and the determinants of search methods use on the sample of successful unemployed searchers in Russia during 1994-2000. 


\section{Data}

We use data from the Russian Longitudinal Monitoring Survey (RLMS) conducted by the Carolina Population Center at the University of North Carolina at Chapel Hill. ${ }^{6}$ The RLMS is the result of an ongoing effort of U.S. and Russian social scientists and officials to measure the impact of market reforms on the living and health conditions of the Russian population. It provides information about migration, work, medical services, use of time, and health evaluation of men, women and children in Russia since the beginning of that country's economic transformation in 1991.

According to the survey designers, the RLMS is the first nationally representative random sample for Russia. It supports both efficient cross-sectional and aggregate longitudinal analyses of change in the Russian household population. The survey is designed as a repeated sample of each household dwelling, much like the decile census in the United States. Thus, instead of following individuals or households from one year to the next, RLMS merely returns to the same dwelling sampled in the previous year. Consequently, by definition, all households who move locally or migrate to another region are automatically lost to follow-up.

The data have been collected in two phases. The first phase consists of four rounds (1-4) between May 1992 and July 1994, while the second phase covers another six rounds (5-10), and is dated between October 1994 and April 2002. We use the information from Phase II (Rounds 5-9), since it reflects a revised questionnaire, and is more refined and consistent among the rounds. Furthermore, the sampling methods

\footnotetext{
${ }^{6}$ The project description at $\underline{w w w . c p c . u n c . e d u / r l m s}$ provides complete information about the RLMS survey and its sampling procedure.
} 
(multi-stage probability sampling) and the conduct of the survey in the second phase proved far superior to those used in the first round. ${ }^{7}$

The analysis in this paper is performed on the pooled data for the following rounds of RLMS/calendar years: Round 5 - 1994, Round 6 - 1995, Round 7 - 1996, Round 8 - 1998, Round $9-2000$. As the survey had not been administered in 1997 and 1999, caution should be used in interpreting the results.

RLMS administers three types of questionnaires: individual, household and community. The research agenda for this project calls for the use of individual and household questionnaires.

The individual questionnaires of Rounds 5, 6, 7, 8 and 9 contain a question: "Are you working?" The choices of answers are: (1) yes (working); (2) maternity leave or leave for taking care of a child under three years old; (3) any other paid leave; (4) unpaid leave; (5) no (not working). If a person answers that $\mathrm{s} / \mathrm{he}$ is not working, $\mathrm{s} / \mathrm{he}$ is asked if s/he would like to find work. The affirmative answer to the question: ["Did you go anywhere or see anyone looking for a job in the last 30 days?"] places an individual into the unemployment category.

Thus, we are only concerned with the 'ILO-style' definition of unemployed ${ }^{8}$, i.e. people who are not working and report looking for a job in the 30 days prior to the survey. The out of work individuals who do not report job search, and individuals experiencing unpaid leave are not included in our sample. In addition, we follow individuals from one round to the next, and only look at those who are unemployed in the

\footnotetext{
${ }^{7}$ Clarke (1999), p.288.

${ }^{8}$ Grogan and Van den Berg (1999).
} 
previous round and are employed in the next round, thus we are only dealing with the successful job searchers.

Individual questionnaires impose six choices of job search methods on those who were not working at the time of the survey and looked for a job in the last 30 days: (1) applying to state employment agencies or labor registry offices; (2) applying to nongovernmental employment services; (3) contacting friends and acquaintances; (4) contacting relatives; (5) applying directly to an enterprise; (6) applying through advertising notices. These methods of job search are the focus of the study. Note that there are no open-ended or "other" choices in the list of search methods. Thus, unfortunately, the survey does not capture any new methods of search, such as Internet use, for example, and any methods that might be specific for Russia, such as informal conversations over a dinner table and protégé, for example.

Due to the small frequencies of responses for such methods as private employment agencies, relatives, and the advertisements (see Appendix 2), we regrouped the methods into broader search strategies as follows:

1. Applying to state and private employment agencies (hereafter, AGENCIES).

2. Working through friends, acquaintances and relatives (CONTACTS).

3. Contacting firms directly and in response to advertisements (FIRMS).

People who used more than one broad search strategy are assumed to have MULTIPLE search.

The socio-economic characteristics of the sample - sex, age, education structure, place of residence and number of children - as well as the search methods' use for pooled data are presented in Appendix 3. 
The quality and availability of data often restrict the possibilities of empirical analysis. The RLMS was conceived as the survey of economic well-being rather than labor force participation. ${ }^{9}$ Therefore, some important labor related information is not existent, and time frame between the rounds, especially with omission of 1997 and 1999 , might be too big to represent the "short period of time" assumed in static labor supply models. On the other hand, the sample is representative of the Russian Federation and is carried on in the same fashion for 10 times during the years of transition, which is in itself a valuable and unique characteristic of any given data set. We recognize some data shortcomings, but follow Heckman's (2000) assessment that “important problems arise from refusing to learn from the data" 10 in constructing economic models. In the following sections we construct a simple job search model for the Russian labor market, and, using RLMS data set, try to learn what we can from the estimation of its parameters.

\section{Economic Model}

The model in this paper follows the methodology of Weber and Mahringer (2002), Eriksson et al (2002), and Stillman (2001) and assumes that at the beginning of each time period, individuals choose whether or not to search for a job in order to maximize their utility. The individual will search for a job this period if the utility of being employed in the next period is greater than the utility of being unemployed in the next period. More formally, given

$$
\begin{array}{lll}
\mathrm{U}_{\mathrm{i}(\mathrm{t}+1)}=\mathrm{V}^{\mathrm{E}} & \text { if } & \mathrm{E}_{\mathrm{i}(\mathrm{t}+1)}=1, \text { or } \\
\mathrm{U}_{\mathrm{i}(\mathrm{t}+1)}=\mathrm{V}^{\mathrm{U}} & \text { if } & \mathrm{E}_{\mathrm{i}(\mathrm{t}+1)}=0,
\end{array}
$$

\footnotetext{
${ }^{9}$ See "About the Study" at the project description page at www.cpc.unc.edu/rlms.

${ }^{10}$ Heckman (2000): p. 88.
} 
where $\mathrm{E}_{\mathrm{it}}=1(0)$ if an individual is (not) employed, $i$ indexes individuals, $t$ indexes time, then, individual $i$ chooses to search for a job at time $t$ if

$$
\mathrm{V}^{\mathrm{E}}>\mathrm{V}^{\mathrm{U}}
$$

In their utility maximization endeavor individuals choose reservation wage and search effort. In this paper we concentrate on the determinants of the individuals' choice of search effort and search methods. The exact amount of search effort is unobservable, we can only observe its proxy which is assumed to be highly correlated with actual search effort. Following Holzer (1988) search effort is approximated by search intensity, which is measured as the number of search methods used. ${ }^{11}$ It is a conventional wisdom that the choice of search intensity and of a particular search strategy varies across individuals according to their skills, background, and place of residence. The measurement of the effects of socio-economic factors on the job search behavior of Russian unemployed is the motivation of this paper.

We follow Eriksson et al (2002) in the decision to decompose search activity into two parts. First, the job seeker decides whether or not to search at all. Second, if search is preferred to no-search, the job seeker decides on how intensively to search and what method(s) to use. Furthermore, we assume that the decision process for searching-or-not is different from that for search intensity and method choice, and, thus, it is important to model search behavior as separate decisions. ${ }^{12}$ Since these decisions are driven by

\footnotetext{
${ }^{11}$ In the literature one can find different methods of measuring search effort. Some studies (Barron and Mellow (1979), Eriksson et.al. (2002)) use the time spent for job search, the others (Kahn and Low (1990)) use number of employer contacts. The third group (Holzer (1988), Weber and Mahringer (2002)) uses the number of methods used during search. The decision to use the number of methods rested on the data availability and is deemed consistent with the analysis of transition countries (Hinnosaar (2003), Roshchin and Markova (2003)).

${ }^{12}$ Labor supply literature emphasizes the importance of distinguishing between, for example, the decisions whether or not to work and the number of hours of work to supply (Killingworth (1983)).
} 
different mechanisms, analyzing search activity and its determinants as a single decision may lead to misleading (policy) conclusions. ${ }^{13}$

Thus, the decision of an individual about the engagement in a job search and about the choice of search intensity and particular search strategy is described by a threeequation structural model of the general form:

$$
\begin{array}{ll}
\mathrm{S}_{\mathrm{it}}=\mathrm{S}\left(\mathrm{X}_{\mathrm{it}}, \mathrm{H}_{\mathrm{it}}, \mathrm{L}_{\mathrm{it}}\right), & \text { (engagement equation) } \\
\mathrm{SI}_{\mathrm{it}}=\mathrm{SI}\left(\mathrm{X}_{\mathrm{it}}, \mathrm{H}_{\mathrm{it}}\right) & \text { (search intensity equation) } \\
\mathrm{SM}_{\mathrm{ijt}}=\mathrm{SM}\left(\mathrm{X}_{\mathrm{it}}, \mathrm{H}_{\mathrm{it}}\right), & \text { (search method choice equation) }
\end{array}
$$

where $\mathrm{S}_{\mathrm{it}}$ is a measure of engagement in the job search activity by the $i$ th individual, $\mathrm{X}_{\mathrm{it}}$ is a set of personal characteristics, $H_{\mathrm{it}}$ is a set of characteristics of individual's household, $\mathrm{L}_{\mathrm{it}}$ is specific labor market characteristics, $\mathrm{SI}_{\mathrm{it}}$ is search intensity or the number of methods used searching, $\mathrm{SM}_{\mathrm{ijt}}$ is a measure of search method use for the $i$ th individual.

Equations (3), (4) and (5) constitute the model of individual i's job search behavior. Given this economic model the next task is to consider an appropriate corresponding statistical model and estimation method.

\section{Statistical Model and Estimation Procedure}

We follow the methodology of Stillman (2000, 2001), Weber and Mahringer (2002), and Eriksson et. al. (2002) in construction of participation equations. These equations -- engagement equation, search intensity equation and search method choice equation -- include all individual, household and employment characteristics as linear independent variables.

\footnotetext{
${ }^{13}$ Eriksson, Lilja and Torp (2002): p. 4.
} 
In particular, let $X_{\mathrm{it}}$ be a vector of individual characteristics, which includes sex, age, education and experience level; $H_{\text {it }}$ be a vector of individual's household characteristics, which includes the number of pre-school age children in the household and place of residence; $\mathrm{L}_{\mathrm{it}}$ be a vector of labor market characteristics, such as wage arrears (unpaid wages or outstanding pay), which accounts for the specific conditions in Russia during the transition period. ${ }^{14}$

Then, defining $\mathrm{S}_{\mathrm{it}}{ }^{*}$ as the unobservable index function underlying individual $i$ 's decision whether to search for work at time $t$, the engagement equation is specified as:

$$
\begin{aligned}
& S_{i t}{ }^{*}=\alpha_{0}+X_{i t} \alpha_{1}+H_{i t} \alpha_{2}+L_{i t} \alpha_{3}+\varepsilon_{i t}, \\
& S_{i t}=1 \quad \text { if } \quad S_{i t}{ }^{*}>0 \text {, } \\
& S_{i t}=0 \quad \text { if } \quad S_{i t}{ }^{*} \leq 0 \text {, }
\end{aligned}
$$

where $\mathrm{S}_{\mathrm{it}}=1(0)$ if individual $i$ is searching (not searching) for a job at time $\mathrm{t} ; \mathrm{X}_{\mathrm{it}}, \mathrm{H}_{\mathrm{it}}$, and $\mathrm{L}_{\mathrm{it}}$ are as described above. The error term, $\varepsilon_{\mathrm{it}}$, is assumed to have a logistic distribution with mean zero and variance normalized to one. ${ }^{15}$ It captures optimization errors along with individual-specific ability and other fixed factors and preferences, which might affect an individual's expected income from employment, their search cost, their reservation utility and relative preference for leisure. ${ }^{16}$

The dependent variable in equation (6) is a dichotomous indicator of whether or not the individual reports searching for a job. Thus the binary logit model is used for estimation. Parameters $\alpha_{1}, \alpha_{2}, \alpha_{3}$, and $\alpha_{4}$ show the propensity to search for a job for different socio-economic groups of individuals.

\footnotetext{
14 Earle and Sabirianova (2002) contains a discussion on wage arrears in Russia.

15 The discrete choice models in this paper are analyzed using maximum likelihood (ML) logit estimation, which requires that the error term follow logistic distribution and have its variance normalized.

${ }^{16}$ We follow Stillman (2001) in stipulating assumptions for the error term.
} 
After making a decision to search for a job an individual decides how intensively to search and which search method to use. Defining the $\mathrm{SI}_{\mathrm{it}}{ }^{*}$ as the unobservable search intensity function for individual $i$ at time $t$, and $\mathrm{SM}_{\mathrm{ijt}}{ }^{*}$ as the unobservable index function underlying individual $i$ 's decision whether to use search method $j$ at time $t$, the reduced form search intensity and search method choice equations are specified as:

$$
\begin{aligned}
& S I_{i t}{ }^{*}=\gamma_{0}+X_{i t} \gamma_{1}+H_{i t} \gamma_{2}+\xi_{i t} \\
& S M_{i j t}{ }^{*}=\beta_{0}+X_{i t} \beta_{1}+H_{i t} \beta_{2}+e_{i j t} \\
& S M_{i j t}=1 \quad \text { if } S M_{i j t}{ }^{*}>0, \\
& S M_{i j t}=0 \quad \text { if } S M_{i j t}{ }^{*} \leq 0,
\end{aligned}
$$

where $\mathrm{SM}_{\mathrm{ijt}}$ is 1 if individual $i$ is using a job search method $j$ at time $t$, and is 0 otherwise.

Equation (7) specifies the influence of personal $\left(\mathrm{X}_{\mathrm{it}}\right)$ and household $\left(\mathrm{H}_{\mathrm{it}}\right)$ characteristics on search intensity $\left(\mathrm{SI}_{\mathrm{it}}{ }^{*}\right)$. The effects are measured by parameter vectors $\gamma_{1}$ and $\gamma_{2}$, respectively. Following Holzer (1988) and Weber and Mahringer (2002) the $\mathrm{SI}_{\mathrm{it}}{ }^{*}$ is approximated by the number of search methods used $\mathrm{SI}_{\mathrm{it}}$, which is ordinal qualitative variable. Higher values of $\mathrm{SI}_{\mathrm{it}}$ are associated with higher search intensity. Accordingly, we estimate equation (7) in an ordinal (ordered) logit specification.

Equation (8) examines the heterogeneity of search method use in personal $\left(\mathrm{X}_{\mathrm{it}}\right)$ and household $\left(\mathrm{H}_{\mathrm{it}}\right)$ characteristics. $\mathrm{SM}_{\mathrm{ijt}} *$ is a $1 \times 3$ vector which can be interpreted as the individual $i$ 's propensity to use each of three broad search strategies identified in the data section above. $\beta_{1}$ is a $1 \times 3$ parameter matrix, the $\mathrm{j}$ 'th row of which corresponds to the influence of explanatory variable $X_{i t}$ on the choice of a particular search strategy. Analogously, $\beta_{2}$ is a $1 \times 3$ parameter vector measuring effect of household characteristics $\left(\mathrm{H}_{\mathrm{it}}\right)$. The error terms, $\xi_{i t}$ and $\mathrm{e}_{\mathrm{ijt}}$, are assumed to be independent and identically distributed across individuals, have mean zero and variance equal to one. 
For the estimation of search method choice $\left(\mathrm{SM}_{\mathrm{ijt}}\right)$ equation (8) we employ the multinomial logit framework. The multinomial logit model gives marginal effects of individual and household factors on the linear predictor of search method choice $\left(\mathrm{SM}_{\mathrm{ijt}}\right)$, and the corresponding effects on the odds. One can also infer the relative propensities of different socio-economic groups to use each search method.

Since following Killingsworth (1983), Holzer (1988) and Eriksson et al (2002) the search activity in our model is decomposed into separate parts of decision process, we first estimate the engagement equation (6), then conditional on the involvement in the job search we, in turn, estimate equations (7) and (8).

Results of application of this model to the RLMS data follow in the next section.

\section{Results}

\subsection{Propensity to Search for a Job}

Table 1 contains the results of binomial logit estimation of the engagement equation (6). ${ }^{17}$ The overall model fit is good as represented by the likelihood ratio statistic (1985.8260 for 9 degrees of freedom), and all coefficient estimates are significant at $5 \%$ level, except the age below 25 years old. One can see that parameter estimates for women and for people older than 50 years of age are negative, which suggests that the likelihood of the active search for new employment decreases for these socio-economic groups. Other parameter estimates are positive, which suggests that people of the 25-50 age group, people with secondary and college education, and residing in metropolitan areas of Moscow and St. Petersburg are more likely to search for a job. Existence of wage arrears increases the likelihood of active search, other things constant. 
Engagement equation (6) theorizes that individual and household characteristics and labor market conditions influence the decision of an unemployed worker to search for a job. In particular, it is conventionally assumed in the labor supply literature that women behave differently than men in their search for employment. It is not surprising to find that in Russian labor market the odds for women to have searched for a job are estimated to be 0.731 times as high as for men, other things being equal. We might interpret this lower propensity to search for women than for men in light of the new economic conditions in Russia. Since the Soviet pressure for equal employment had ended, women realize more choices in their labor force participation. They might have engaged in the individual entrepreneurial activity (charter shopping trips abroad, for example), which does not involve a formal job search process. Additionally, women, in particular, might have been moving between "unobserved" and official economies ${ }^{18}$, which would prompted them to say that they are not actively searching for a job. Interestingly, the lower search propensity for women in Russia is consistent with the estimates for Nordic countries $^{19}$. It is surprising, however, that women would behave so similar in such different economic environments.

The factor closely related to sex differences in labor market behavior is the household composition. The literature emphasizes that the existence of small children in the family would alter the preferences for work per se, for hours worked and reservation wage. Our model includes the categorical variable that measures the presence of children of pre-school age (0-7 years old) in the household. We found that the odds of searching

${ }^{17}$ Appendix 4 contains the summary statistics for variables used in the engagement equation estimation.

${ }^{18}$ Official estimate of unobserved (unrecorded or underground) economy in Russia is about $30 \%$. It is also believed to be a substitute to the official economy, meaning that people move in and out of it fairy quickly 
for a job for individuals that have pre-school age children in the household are 1.197 times higher than for individuals that do not have children of that age in the household, ceteris paribus. This higher propensity to search for a job could be the outcome of at least two factors: 1) the existence of small child(ren) would prompt both parents to look for additional income especially during the high inflation period that occurred in Russia in 1994-2000; 2) the availability of high quality free day-care facilities, would allow parents, and especially mothers, to engage in job search more actively.

The labor supply theory suggests that women's decisions about labor force participation and job search behavior might be disproportionally affected by the existence of small children in the household. In one of our model's specifications we interacted the sex variable with the "children" variable but found no statistical significance in any of the three equations $(6,7$ and 8). Thus we concluded that for our sample there are no significant differences in the job search behavior of men and women due to the presence of pre-school age children in the household, and the effort of inclusion of such interaction variable was abandoned.

The age factor is hypothesized to have a significant effect on the propensity to search. In fact, the odds for people in the age group of 25-50 years old to have been searching for a job are estimated to be 2.156 times higher than for other age groups, ceteris paribus. On the other hand, the odds for older age group to have been searching are estimated to be lower than for other age groups (odds ratio $=0.189$ ). These results are intuitively appealing since one would expect unemployed people in their prime work age

and freely depending on the change in economic conditions. (For unobserved economy estimations for Russia see Rosser et. al. (2001), Alexeev and Pyle (2001), and Feige (2003).)

19 See Eriksson et. al. (2002): Table 3, p.14. 
(25-50 years old) to be most actively searching for jobs. In the context of our model the benefits of search for this age group are likely to exceed the costs by a wide margin.

At the age of over 50 years old the propensity to search would decline, mainly because of closeness of retirement age, which is 55 for women and 60 for men in Russia. In particular, during the time period of this analysis (1994-2000) the early retirement packages were offered very often, especially to women. The decreased propensity to search for older workers is consistent with the labor supply literature and with Eriksson et. al. (2002) estimates for Finland and Norway.

Theory hypothesizes that educational attainment influences the individual's utility function and expected lifetime earnings pattern, and so education is considered to be an important factor in the job market. In our analysis we separate people who received secondary education (professional courses or professional technical school (approximately 1-3 years of studies beyond high school)) and those who received college education (institute or university (at least 5 years beyond high school)). These education levels are not mutually exclusive in RLMS sample, thus we use two separate categorical variables to capture the highest educational level achieved. The likelihood of engaging in the job search is estimated to increase for people with both levels of education (positive coefficients). In particular, the odds for workers with completed secondary education to have searched for a job are 1.669 times higher than for people without such education, other things equal. The odds for workers with college education are 1.518 times higher than for people without such education, ceteris paribus. Thus, people with secondary education, in fact, are searching more actively than people with college degrees. 
The search theory and our model suggest that search costs and productivities vary across the places of residence of the individuals. It is therefore reasonable to hypothesize that Russian Federation, which is very big in territory and diverse in urban/rural structure, would exhibit geographical differences in the functioning of the labor market. However, we did not find significant differences among the eight regions ${ }^{20}$ identified in the RLMS $^{21}$. The reason may be in the limited inter-region movements of labor ${ }^{22}$, and locality of the job search. Consequently, in this paper we choose to explore the importance of living in the metropolitan areas of Moscow and St. Petersburg (Region 1 in RLMS) in contrast to the other regions of Russia (regions 2 through 8 in the RLMS). ${ }^{23}$ It turns out that the propensity to search is higher for residents of Region 1 than for residents of other regions of Russia. In fact, the odds of searching for a job by Moscow and St. Petersburg denizens are 1.700 times higher than for populace of other regions, other things equal. This result seems plausible, as one would expect the labor market to be more developed, flexible and presenting more opportunities for searchers in urban areas such as Moscow and St. Petersburg. These opportunities are worth exploring, and thus search more actively in these cities.

Specific labor market conditions are the critical characteristics of the transition countries. Wage arrears (unpaid wages or outstanding pay), in particular, are considered to be a distinctive feature of Russian labor market adjustment and are argued to hinder the

\footnotetext{
${ }^{20}$ Eight regions in RLMS correspond to the administrative division of Russian Federation.

${ }^{21}$ See Smirnova (2002).

${ }^{22}$ For example, Andrienko and Guriev (2003) concluded that region-to-region migration flows in Russia during 1992-1999 are low.

${ }^{23}$ Such decision is consistent with other studies of job search behavior. For example, Weber and Mahringer (2002) consider "Living in Large City" as one of the explanatory variables in the analysis of Austrian labor market.
} 
structural change in Russia as compared to CEE countries. ${ }^{24}$ Existence of wage arrears is supposed to capture those specifics for Russian labor market in our analysis. Up to date wage arrears in Russia were examined only in the relation to the employmentunemployment transitions, i.e. workers' quit behavior. Earle and Sabirianova (2002) argue that conceptually the effect of delayed wages on an employee's mobility is ambiguous and show empirically that the probability of the worker quitting in response to late wages is positive in the regions with low wage arrears but negative in regions where they are high. The effect of unpaid wages on the behavior of individuals after they quit a job and are looking for the new one would then be ambiguous as well.

RLMS contains a question: "At present time, does your place of work owe you any money, which for various reasons was not paid on time?" The answers to this question comprise the categorical variable of wage arrears in our sample. The estimate shows that the propensity to search for a job for workers who have wage arrears is higher than for workers that do not experience such situation (odds ratio $=1.726$ ). If we account for the fact that the incidence of wage arrears is quite low in our sample (around $5 \%$, see Appendix 4), the higher propensity to search is consistent with the evidence presented by Earle and Sabirianova (2002).

\subsection{Job Search Intensity}

Table 2 contains the ordinal logit estimation results for job search intensity. ${ }^{25}$ The sample now consists of people who have searched for a job in the last 30 days and used one or several single search methods in their search. The overall fit of the model is good,

\footnotetext{
${ }^{24}$ See Earle and Sabirianova (2002) for analysis of wage arrears in Russia, and Boeri and Terrell (2002) for comparison of labor market adjustment paths among transition countries.
} 
with likelihood ratio Wald chi-square statistics being 30.2824 for 6 degrees of freedom. All effects considered in the model are significant except the presence of pre-school age children in the household. The score test for proportional odds assumption is passed.

Search intensity is measured by the number of search methods used (1-6), and ordered so that the larger numbers of methods used correspond to the higher level of search intensity. The average number of search methods used in Russia is 2.22 for successful searchers in the RLMS sample ${ }^{26}$. This figure is consistent with Roshchin and Markova's (2003) estimate of search intensity for unemployed workers for the period of 1994-2000 in the RLMS sample ${ }^{27}$.

Labor supply theory, as well as equation (7), hypothesizes that sex, education, experience, household composition and place of residence affect search intensity of unemployed individual. The estimates in Table 2 suggest that women in Russia search less intensely than men. In particular, the odds for women to have used 2 instead of 1 search method are about 0.787 times as high as for men, other things equal. Similarly, the odds for women to use 3 instead of 1 and 2 search methods are about 0.787 times as high as for men, other things equal. This result is consistent with lower search intensity for women then for men in Estonia ${ }^{28}$, Finland and Norway ${ }^{29}$. However, in Austria women are searching more intensely than $\operatorname{men}^{30}$.

Search intensity declines with work experience. Other things being equal, each additional year of experience diminishes the odds of higher intensity by the factor of

${ }^{25}$ Appendix 5 contains summary statistics for variables used in the estimation of search intensity equation.

${ }^{26}$ See Appendix 3.

${ }^{27}$ Search intensity for unemployed is estimated to vary between 2.1 and 2.7 methods during the period of 1994-2000.

${ }^{28}$ Hinnosaar (2003).

29 Erikkson et al (2002).

${ }^{30}$ Weber and Mahringer (2002). 
0.987. This may be because the experience in the labor market allows to limit the search to one or two methods that proved to be successful. Additionally, since age and experience level are highly correlated ${ }^{31}$, this estimate is consistent with the conclusions of other researchers that search effort diminishes with age. ${ }^{32}$

Search literature emphasizes that education plays an important role in the effort devoted to the job search by raising lifetime income and the opportunity costs of not searching. Our estimation shows that people with education search more intensely than people without, other things equal. For example, table 2 shows that the odds for people with secondary education to use more search methods are 1.285 times higher than for people without such education. The odds for people with college education to use 2 instead of 1 , or 3 instead of 1 and 2, methods are 1.528 times higher than for people without such education. As in search propensity case, people with college education search relatively more intense than people with just secondary education. Higher returns to a year of education in transition economies ${ }^{33}$, greater innate motivation and ambition would be plausible explanations for this result.

Place of residence, as expected, has a significant positive effect of the job search effort. People living in Moscow and St. Petersburg search more intensely than people living in other regions, other things equal (odds ratio is 1.519). The search theory suggests that in urban labor markets the costs of search are lower due to the high density of employers and lower transportation costs, for example, and real returns are higher due to the real wage premia that exists in urban compared to non-urban labor markets. Our result is, thus, consistent with the hypothesis that the increased job opportunities in

${ }^{31}$ Pearson correlation coefficient is 0.84876 .

${ }^{32}$ Weber and Mahringer (2002). 
metropolitan cities of Moscow and St. Petersburg, in addition to the flexibility of labor market, high density of employers, and increased access to the information are expected to positively influence people's job search intensity.

Table 3 gives the predicted probabilities of the average number of methods used by unemployed in Russia. The use of only one job search method has the highest predicted probability $(\approx 42 \%)$. The predicted probabilities of using more than one method gradually decline in the sample (from $21 \%$ for two methods down to $2 \%$ for six methods). The predicted probabilities are consistent with the descriptive statistics for this sample (see Appendix 8).

\subsection{Search Methods Use}

Search method choice equation (8) is estimated using the multinomial logit procedure. Crucial restriction of this procedure is the mutual exclusiveness of the choice alternatives, i.e. search methods used by unemployed in our case. Therefore, in this section we further restrict our sample to the individuals who used only one search method. The frequencies of use of single search methods identified in RLMS are presented in Appendix 2. Due to disproportionally small number of observations for such methods as adds, relatives and private employment services we re-grouped the search methods into three broad strategies, as described in section 3: AGENCIES; CONTACTS and FIRMS. Accordingly, our sample now consists of 557 successful job searchers who used one of the three broad strategies.

\footnotetext{
${ }^{33}$ See discussion in section 2 on stylized facts of the transitional labor markets.
} 
Results of the multinomial logit estimation of the search method choice equation for three specifications based on the comparison category are presented in Table $4^{34}$. The overall fit of the search method choice equation is good with likelihood ratio Wald chisquare statistic of 50.1342 for 12 degrees of freedom. The variables with statistically significant coefficients are sex, work experience and residence in the metropolitan areas of Moscow and St. Petersburg. Since the odds ratios have an intuitive appeal for the interpretation, we would concentrate on the odds ratios presented in Table 5.

Search theory hypothesizes that women use different job search strategies to look for a job compared to men. These differences are expected to be more profound in Russia because since Soviet times a highly inequitable distribution of social and domestic labor towards women was observed ${ }^{35}$. It is interesting to see if sex inequality issues play any role in the job search behavior in transitional Russia. The model estimation predicts the odds for women to have used AGENCIES instead of FIRMS are 2.149 times higher than the same odds for men. The odds for women to have used the AGENCIES instead of CONTACTS are 2.275 times higher than the same odds for men. From these estimates one can infer that compared to men women are using AGENCIES more often than any other strategy. In our opinion, the absence of "equal opportunity" legislation in Russia might influence the discrimination against women in the labor market. Thus, women may feel more secure applying through the employment agencies when looking for reemployment rather than through direct contact with the employers or through personal contacts.

\footnotetext{
${ }^{34}$ Appendix 8 contains summary statistics for variables used in the estimation of search method choice equation.

35 Harrison (1986): pp. 78-79.
} 
Work experience is hypothesized to influence the individual's reservation wage and thus search behavior. In particular, the search method choice is affected because individuals with greater experience in the labor market would use more personal or informal contacts or develop specific strategies in looking for a job. Our estimation shows that each additional year worked would increase the odds of applying through FIRMS instead of CONTACTS by the factor of 1.029, and would increase the odds of applying through AGENCIES instead of CONTACTS by the factor of 1.022, other things equal. These results surprisingly exhibit the decline of probability of usage of CONTACTS relative to other methods with increase of experience, which is counterintuitive. But some search strategies, for example informal contacts, which might be widely used by more experienced workers in Russia, are not captured by the RLMS, as described in section 2. Moreover, due to a decrease of returns to experience in all transition countries ${ }^{36}$, more experienced individuals might tend to apply through the AGENCIES, which offer re-training and referrals, or directly through FIRMS, where they might have some prior contacts with the administration.

Residence in metropolitan areas of Moscow and St. Petersburg (Region 1) has the largest effect on the choice of job search strategies. The odds for people living in Region 1 to have applied through CONTACTS instead of AGENCIES are 8.185 times higher than for people living in other regions. The odds for workers in Region 1 to have used FIRMS as their job search strategy instead of AGENCIES are 8.483 times higher than for people living in other regions. Thus one can see that AGENCIES are the least probable search strategy for unemployed individuals living in Region 1. The FIRMS strategy seems to be more probable than CONTACTS for Region1, but this difference is not

${ }^{36}$ See discussion of stylized facts of labor markets in transition economies in Section 2. 
significant. These results are consistent with the conventional wisdom and the reasonable economic prediction that living in large city increases the density of employers in one's region, and thus reduces costs of job search. In this case Moscow and St. Petersburg definitely stand out in terms of developed labor market infrastructure (advertisements), and the extent of personal contacts (friends and relatives) that being utilized.

\section{Conclusions}

This paper investigates the job search behavior of Russian unemployed and specifically addresses three issues in the development of Russian labor market: (1) propensity to search for a job after having been unemployed; (2) search intensity of successful job seekers; and (3) the use of specific search methods when searching. We use the RLMS data of Rounds 5-9 to estimate the engagement in search equation, search intensity equation, and search method choice equation.

The following limitations of the data and estimation are encountered: nonexistence of important labor related information since RLMS is a survey of "economic well-being"37 rather than of "labor force"; annual data collection intervals which might be too big to represent "short period of time" assumed in static labor supply model; decreased sample size when accounted for restriction of mutual exclusiveness of multinomial logistic regression. We recognize these shortcomings and, thus, exercise extra caution in interpreting the results.

On average a successful job searcher in Russia uses 2 methods. Approximately $17 \%$ of searchers use CONTACTS (relatives, friends and acquaintances) as their job leads, $13 \%$ use AGENCIES (state and private employment services) as their search 
strategy, $12 \%$ apply to FIRMS (through advertisements and directly), and $57 \%$ use the strategy of combination of different methods.

The results of the three-equation model estimation are summarized in Table 6 . The econometric evidence suggests that:

1) regarding the propensity to search, workers in the $25-50$ years old age group, with a completed secondary or college education, with children of the pre-school age in the household, or living in the metropolitan areas of Moscow and St. Petersburg have a higher propensity to search for a job. Such factors as being female or belonging to the older age group reduces the propensity to search. Additionally, labor market characteristics, such as wage arrears, increase search propensity;

2) regarding search effort, women and people with more experience search less intensely. However, workers with secondary or college education, or living in Moscow and St. Petersburg metropolitan areas search for jobs more intensely.

3) regarding specific methods of job search, their use does differ across socioeconomic groups. Women are more likely to apply to AGENCIES than use other search strategies. People with more experience are more likely to use FIRMS and AGENCIES instead of CONTACTS for their job leads. Residents of the metropolitan areas of Moscow and St. Petersburg are more likely to use CONTACTS and FIRMS instead of AGENCIES.

Overall, sex differences and residence in Moscow and St. Petersburg metropolitan areas are estimated to be consistently statistically important for job search behavior. Women are significantly less active than men in all stages of job search. Explanation for that might lie in somewhat traditional family arrangements that are still cultivated in

${ }^{37}$ See "About the Study" at the project description page at www.cpc.unc.edu/rlms. 
Russia. Customarily women are expected to perform all household duties in addition to being employed full-time. Thus, women are less likely to engage in job search, they lag behind men in intensity of search, and differ from men in their search strategy.

Job search behavior of workers living in metropolitan areas of Moscow and St. Petersburg is estimated to differ significantly from the behavior of workers living in other regions of Russia. The concentration of employers, informational infrastructure development, density of personal contacts and other specifics of the labor market in Moscow and St. Petersburg in fact encourage the activity of labor market participants.

The fact that overall search intensity, as well as its allocation across methods, are chosen differently by different individuals suggests that the specifics of search behavior are the important part of functioning of the labor market in Russia, as the model suggests they should be. More research is needed, however, to advance our understanding of the search behavior of unemployed workers in Russia. In particular, the productivity of each search method could be addressed, and the demand side of the Russian labor market should be explored using a different data set, however. 


\section{Table 1. Propensity to Search for a Job}

$$
\text { (Logit Estimation, Probability Modeled is Search=1) }
$$

\begin{tabular}{|l|c|c|c|}
\hline \multicolumn{1}{|c|}{ Explanatory Variable } & Estimate & St.Error & Odds Ratio \\
\hline Intercept & -1.6581 & 0.1310 & \\
Female & -0.3135 & 0.0549 & 0.731 \\
Age <25 & $0.0691 \#$ & 0.1229 & 1.072 \\
Age 25-50 & 0.7681 & 0.1227 & 2.156 \\
Age >50 & -1.6643 & 0.1358 & 0.189 \\
Secondary Education & 0.5122 & 0.0558 & 1.669 \\
College Education & 0.4176 & 0.0902 & 1.518 \\
Residence in Region 1 & 0.5307 & 0.0983 & 1.700 \\
Presence of Children 0-7 years old & 0.1799 & 0.0639 & 1.197 \\
Wage Arrears & 0.5460 & 0.0941 & 1.726 \\
\multicolumn{2}{|c|}{ N } & 13286 & \\
\hline Dikelihood Ratio Chi-Square & 1985.8260 & & \\
DF Chi-Square & 9 & & \\
\hline
\end{tabular}

Notes:

1) All estimates are significant at 5\% significance level, except the one labeled with \#.

2) All variables are categorical variables: $=1$ when the characteristic is present, and $=0$ otherwise. The reference category for all explanatory variables is ' 0 '. 
Table 2. Job Search Intensity Equation

(Ordinal Logit Estimation, Probabilities Modeled are of Higher Search Intensity)

\begin{tabular}{|l|c|c|c|}
\hline \multicolumn{1}{|c|}{ Explanatory Variable } & Estimate & Standard Error & Odds Ratio \\
\hline Female & -0.1196 & 0.0552 & 0.787 \\
Number of Years Worked & -0.0126 & 0.0046 & 0.987 \\
Secondary Education & 0.1253 & 0.0568 & 1.285 \\
College Education & 0.2119 & 0.0808 & 1.528 \\
Presence of Children 0-7 years old & $-0.0171 \#$ & 0.0623 & 0.966 \\
Residence in Region 1 & 0.2091 & 0.0884 & 1.519 \\
\hline \multicolumn{1}{|c|}{ N } & 1097 & & \\
Likelihood Ratio & 30.2824 & & \\
DF & 6 & & \\
\hline
\end{tabular}

Notes:

1) All estimates are significant at 5\% significance level except the one labeled with \#.

2) All explanatory variables, except number of years worked, are categorical variables: $=1$ when the characteristic is present, and $=0$ otherwise. The reference category for these variables is ' 0 '.

Table 3. Predicted Probabilities of Average Number of Methods to be Used (Ordinal Logit Estimation)

\begin{tabular}{|c|c|}
\hline $\begin{array}{c}\text { Average Number of Search } \\
\text { Methods to be Used }\end{array}$ & $\begin{array}{c}\text { Predicted } \\
\text { Probability }\end{array}$ \\
\hline 1 & 0.4193 \\
2 & 0.2138 \\
3 & 0.1645 \\
4 & 0.1186 \\
5 & 0.0591 \\
6 & 0.0246 \\
\hline N & 1097 \\
\hline
\end{tabular}


Table 4. Search Method Choice Equation

(Multinomial Logit Estimates)

\begin{tabular}{|c|c|c|c|c|c|c|}
\hline \multirow{2}{*}{ Parameter } & \multicolumn{2}{|c|}{ Contrast with AGENCIES } & \multicolumn{2}{|c|}{ Contrast with FIRMS } & \multicolumn{2}{|c|}{ Contrast with CONTACTS } \\
\hline & CONTACTS & FIRMS & CONTACTS & AGENCIES & FIRMS & AGENCIES \\
\hline Female & $\begin{array}{c}-0.4111^{*} \\
(0.1178)\end{array}$ & $\begin{array}{c}-0.3824 \text { * } \\
(0.1249)\end{array}$ & $\begin{array}{c}-0.0287 \\
(0.1172)\end{array}$ & $\begin{array}{l}0.3824 \text { * } \\
(0.1249)\end{array}$ & $\begin{array}{c}0.0287 \\
(0.1172)\end{array}$ & $\begin{array}{l}0.4111^{*} \\
(0.1178)\end{array}$ \\
\hline Number of Years Worked & $\begin{array}{l}-0.0217 * \\
(0.00885)\end{array}$ & $\begin{array}{c}0.00729 \\
(0.00890)\end{array}$ & $\begin{array}{c}-0.0290 \text { * } \\
(0.0089)\end{array}$ & $\begin{array}{c}-0.0073 \\
(0.0089)\end{array}$ & $\begin{array}{l}0.0290 * \\
(0.0089)\end{array}$ & $\begin{array}{l}0.0217^{*} \\
(0.0089)\end{array}$ \\
\hline Secondary Education & $\begin{array}{l}-0.0147 \\
(0.1156) \\
\end{array}$ & $\begin{array}{c}0.0535 \\
(0.1231) \\
\end{array}$ & $\begin{array}{c}-0.0682 \\
(0.1186) \\
\end{array}$ & $\begin{array}{l}-0.0535 \\
(0.1231)\end{array}$ & $\begin{array}{c}0.0682 \\
(0.1186) \\
\end{array}$ & $\begin{array}{c}0.0147 \\
(0.1156)\end{array}$ \\
\hline College Education & $\begin{array}{c}-0.0163 \\
(0.1798)\end{array}$ & $\begin{array}{c}-0.1988 \\
(0.1983)\end{array}$ & $\begin{array}{c}0.1824 \\
(0.1880)\end{array}$ & $\begin{array}{c}0.1988 \\
(0.1983)\end{array}$ & $\begin{array}{c}-0.1824 \\
(0.1880)\end{array}$ & $\begin{array}{c}0.0163 \\
(0.1798)\end{array}$ \\
\hline Residence in Region 1 & $\begin{array}{l}1.0511 \text { * } \\
(0.3184)\end{array}$ & $\begin{array}{l}1.0690 \text { * } \\
(0.3249)\end{array}$ & $\begin{array}{l}-0.0179 \\
(0.1836)\end{array}$ & $\begin{array}{c}-1.0690 \text { * } \\
(0.3249)\end{array}$ & $\begin{array}{c}0.0179 \\
(0.1836)\end{array}$ & $\begin{array}{c}-1.05111^{*} \\
(0.3184)\end{array}$ \\
\hline Presence of Children 0-7 years old & $\begin{array}{c}0.1704 \\
(0.1283)\end{array}$ & $\begin{array}{c}0.1830 \\
(0.1373)\end{array}$ & $\begin{array}{l}-0.0126 \\
(0.1284)\end{array}$ & $\begin{array}{l}-0.1830 \\
(0.1373)\end{array}$ & $\begin{array}{c}0.0126 \\
(0.1284)\end{array}$ & $\begin{array}{c}-0.1704 \\
(0.1283)\end{array}$ \\
\hline $\begin{array}{c}\mathrm{N} \\
\text { Likelihood Ratio } \\
\mathrm{DF} \\
\mathrm{Pr}>\mathrm{Chi}-\mathrm{Sq} \\
\end{array}$ & $\begin{array}{c}462 \\
50.1342 \\
12 \\
<0.0001 \\
\end{array}$ & & & & & \\
\hline
\end{tabular}

Notes: $\quad$ Standard Errors are in parentheses;

* means statistical significance at 5\% level. 
Table 5. Odds Ratios for the Search Method Choice Equation

(Multinomial Logit Estimation)

\begin{tabular}{|l|c|c|c|c|c|c|}
\hline \multirow{2}{*}{ Parameter } & \multicolumn{2}{|c|}{ Contrast with AGENCIES } & \multicolumn{2}{c|}{ Contrast with FIRMS } & \multicolumn{2}{c|}{ Contrast with CONTACTS } \\
\cline { 2 - 7 } & CONTACTS & FIRMS & CONTACTS & AGENCIES & FIRMS & AGENCIES \\
\hline Female & $0.440^{*}$ & $0.465^{*}$ & 0.944 & $2.149^{*}$ & $1.059^{*}$ & $2.275^{*}$ \\
Number of Years Worked & $0.979^{*}$ & 1.007 & $0.971^{*}$ & 0.993 & $1.029^{*}$ & $1.022^{*}$ \\
Secondary Education & 0.971 & 1.113 & 0.873 & 0.899 & 1.146 & 1.030 \\
College Education & 0.968 & 0.672 & 1.440 & 1.488 & 0.694 & 1.033 \\
Residence in Region 1 & $8.185^{*}$ & $8.483^{*}$ & 0.965 & $0.118^{*}$ & 1.036 & $0.1222^{*}$ \\
Presence of Children 0-7 years old & 1.406 & 1.442 & 0.975 & 0.693 & 1.026 & 0.711 \\
\hline
\end{tabular}

$\mathrm{N}=462$

Note: $\quad *$ means that the parameter estimates for which the odds ratios are calculated are significant at $5 \%$ significance level. 
Table 6. Summary of the Effects of Explanatory Variables on the Likelihood of the Response Variables

\begin{tabular}{|c|c|c|c|}
\hline$x$ & $\begin{array}{c}\text { Likelihood of } \\
\text { Propensity to Search } \\
\text { with the Presence of } X\end{array}$ & $\begin{array}{c}\text { Likelihood of } \\
\text { Higher Search Intensity } \\
\text { with the Presence of X }\end{array}$ & $\begin{array}{c}\text { Likelihood of } \\
\frac{\text { Particular Search Method Use }}{\text { with the Presence of } X}\end{array}$ \\
\hline $\begin{array}{c}\text { Female } \\
\text { Age }<25 \text { years old } \\
\text { Age } 25-50 \text { years old } \\
\text { Age }>50 \text { years old } \\
\text { Years of Experience } \\
\text { Secondary Education } \\
\text { College Education } \\
\text { Presence of Children 0-7 years old } \\
\text { Residence in Moscow and St.Petersburg } \\
\text { Wage Arrears }\end{array}$ & $\frac{1}{4}$ & $\begin{array}{l}\downarrow \\
\boldsymbol{\uparrow} \\
\hat{\uparrow} \\
\boldsymbol{\uparrow} \boldsymbol{\uparrow}\end{array}$ & $\begin{array}{l}\text { AGENCIES > FIRMS \& CONTACTS } \\
\text { FIRMS \& AGENCIES > CONTACTS } \\
- \\
\text { CONTACTS \& FIRMS > AGENCIES }\end{array}$ \\
\hline
\end{tabular}




\section{Bibliography}

Addison, John T., and Portugal, Pedro. 2001. Job Search Methods and Outcomes. IZA Discussion Paper No. 349.

Alexeev, Michael, and Pyle, William. 2001. A Note on measuring the Unofficial Economy in the Former Soviet Republics. WDI Working Paper No. 436.

Andrienko, Y., and Guriev, S. 2003. Determinants of Interregional Mobility in Russia: Evidence from Panel Data. CEFIR, Moscow, February 2003.

Barron, J. and Mellow, W. 1979. Search Effort in the Labor Market. Journal of Human Resources, 14: 389-404.

Blau, D.M., and Robins, P.K. 1990. Job Search Outcomes for the Employed and Unemployed. Journal of Political Economy, 98: 637-655.

Boeri, Tito, and Terrell, Katherine. 2002. Institutional Determinants of Labor Reallocation in Transition. Journal of Economic Perspectives, Vol. 16, Number 1, Winter 2002: pp.51-76.

Denisova, I. 2003. Russia's Federal Employment Service. Transition Newsletter, Volume 14, No.1-3: 33 .

. 2002. Staying Longer on unemployment Register in Russia: Lack of Education, Bad Luck or Something Else? CEFIR Working Paper.

Earle, John S., and Sabirianova, Klara Z. 2002. How Late to Pay? Understanding Wage Arrears in Russia. Journal of Labor Economics, July 2002, Vol.20, Number 3: pp. 661-707.

Eriksson, Tor; Lilja, Reija; Torp, Hege. 2002. Determinants of Job Search Intensity - Some Evidence from the Nordic Countries. Paper presented at the EALE 2002 Annual Conference at Sorbonne, Paris, September, 21, 2002.

Fedge, Edgar L. 2003. The Dynamics of Currency Substitution, Asset Substitution and De facto Dollarization and Euroization in Transition Countries. Working Paper and Presentation at the BOFIT Workshop, June 26, 2003, Helsinki, Finland. Forthcoming in Comparative Economic Studies, Fall 2003.

Foley, Mark C. 1997. Labor Market Dynamics in Russia. Yale University, Economic Growth Center Discussion Paper No.780.

Geishecker, Ingo; Haisken-DeNew, John P. 2002. Riding the Transitional Roller-Coaster: Flexibility and the Inter-Industry Wage Structure in Russia. DIW Berlin, German Institute for Economic Research, Discussion Paper \# 280.

Gimpelson, Vladimir, and Lippoldt, Douglas. 1999. Private Sector Employment in Russia. Economics of Transition, 7(2): 505-533.

Gregg, P. and Wadsworth, J. 1996. How Effective Are State Employment Agencies? Jobcentre Use and Job Matching in Britain. Oxford Bulletin of Economics and Statistics, 58, 43-67. 
Grogan, Louise, and Van den Berg, Gerard. 1999. The Duration of Unemployment in Russia. CEPR Discussion Paper No.2268.

Ham, John; Svejnar, Jan, and Terrell, Katherine. 1998. Unemployment and the Social Safety Net During Transitions to a Market Economy: Evidence from the Czech and Slovak Republics. The American Economic Review, 88(5), May 1998: 1117-1142.

Harrison, Mark. 1986. Lessons of Soviet Planning for Full Employment. In Labour and Employment in the USSR. Edited by David Lane, Harvest Press, UK, Ch.5: pp.69-82.

Heckman, J.J. 2000. Causal Parameters and Policy Analysis in Economics: A Twentieth Century Retrospective. The Quarterly Journal of Economics, February 2000: 45-97.

Hinnosaar, Marit. 2003. The Impact of Social Protection System on Unemployment in Estonia. Bank of Estonia, Working Paper presented at the BOFIT Research Seminar, May 19, 2003.

Holzer, Harry J. 1988. Search Method Use by Unemployed Youth. Journal of Labor Economics, 6(1): 1-20.

International Monetary Fund. 2003. IMF Country Report No.03/145. Russian Federation: Statistical Appendix.

Kahn, L. and Low, S. 1990. The Demand of Labor Market Information. Southern Economic Journal, 56: 1044-1058.

Killingsworth. 1983. Labor Supply. Cambridge University press, Cambridge.

Layard, Richard, and Richter, Andrea. 1995. How Much Unemployment is Needed for Restructuring: the Russian Experience. Economics of Transition, Vol.3, No.1: 39-58.

Liao, Tim Futing. 1994. Interpreting Probability Models: Logit, Probit, and Other Generalized Linear Models. Sage University Paper series on Quantitative Applications on the Social Sciences, 07-101. Newbury Park, CA: Sage.

Lindenboom, M., Van Ours, J., and Renes, G. 1994. Matching Employers and Workers: an Empirical Analysis on the Effectiveness of Search. Oxford Economic Papers, 46 (1): 45-67. Lubyova, M., and Van Ours, J.C. (1997) Work Incentives and the probability of Leaving Unemployment in Slovak Republic. WDI Working Paper No.82.

Maddala, G.S. 1983. Limited-Dependent and Qualitative Variables in Econometrics. Cambridge University Press.

Mortensen, Dale T. 1999. New Developments in Models of Search in the Labor Market. In Handbook of Labor Economics, Vol.3, Edited by_O. Ashenfelter and R. Layard, Ch.39, Elsevier Science Publishers BV: 2567-2627.

$$
\text { 1986. Job Search and Labor Market Analysis. In Handbook of Labor }
$$

Economics, Vol. II, Edited by O. Ashenfelter and R. Layard, Ch.15, Elsevier Science Publishers BV: $849-919$ 
Osberg, L. 1993. Fishing in Different Pools: job-search strategies and job-finding success in Canada in the early 1980s. Journal of Labor Economics, 11: 348-386.

Roshchin, S.U, and Markova, K.V. 2003. Выбор каналов поиска работы на Российском рынке труда. Финальный отчет. EERC, Moscow, June 2003.

Rosser, J. Barkley, Rosser, Marina V., and Ahmed, Ehsan. 2001. Multiple Unofficial Economy Equilibria and Income Distribution Dynamics in Systemic Transition. Paper Presented at the EEA 2002 Meetings in Boston, March 2002.

Sabirianova, Klara Z. 2000. The Great Human Capital Reallocation: An Empirical Analysis of Occupational Mobility in Transitional Russia. WDI Working Paper No.309.

Schüle, U. 2003. Management of Labour Market Policies in Russia. Proceedings of the $5^{\text {th }}$ International Conference "Enterprise in Transition", May 22-24, 2003, Split, Croatia: 167-171.

Smirnova, Natalia. 2002. Job Search Strategies of Russian Unemployed. Proceedings of the European Association of Labour Economists (EALE) 2002 Annual Conference, University of Paris I, Sorbonne, Paris, September.

Stillman, Steven. 2001. Why Are Employment Rates So Low in Russia? RAND Labor and Population Program Working Paper. . 2000. The Determinants of Private and Government Sector Earnings in Russia. RAND Labor and Population Program Working Paper 00-17.

Vodopivec, M. 1995. Unemployment Insurance and Duration of Unemployment: Evidence from Slovenia's Transition. World Bank Policy Research Working Paper No. 1552.

Weber, Andrea, and Mahringer, Helmut. 2002. Choice and Success of Job Search Methods. Austrian Institute for Advanced Studies, IHS Economic Series, Working Paper No.125. 


\section{$\underline{\text { Appendix } 1}$}

Table A1.1. Labor Markets: Comparison among Countries

\begin{tabular}{|c|c|c|c|c|}
\hline Indicator & EU-15, 2002 & ACC, 2002 & USA, 2002 & Russia, 2001 \\
\hline $\begin{array}{l}\text { Population -- total, million } \\
\text { Total Employment, thousand } \\
\text { Employm ent Rate -- } 15-64 \text { years, } \% \\
\text { Unemploym ent, thousand } \\
\text { Unemployment Rate -- } 15+\text { years, } \% \\
\text { Unemployment by Duration, \% } \\
\quad-\text { less than } 6 \text { months } \\
\quad-6 \text { to } 11 \text { months } \\
-12 \text { months and more }\end{array}$ & $\begin{array}{c}374.8 \\
162,974 \\
64.2 \\
13,453 \\
7.6 \\
42.2 \\
17.6 \\
40.2\end{array}$ & $\begin{array}{c}66.7 \\
28,917 \\
56.1 \\
5,012 \\
14.8 \\
24.7 \\
21.0 \\
54.3\end{array}$ & $\begin{array}{c}281.4(\#) \\
136,439 \\
62.4 \\
8,378 \\
6.0 \\
\\
81.6 \\
9.8 \\
8.5\end{array}$ & $\begin{array}{c}144.2 \\
64,664 \\
58.6 \\
6,303 \\
8.9 \\
45.0 \\
18.0 \\
36.9\end{array}$ \\
\hline
\end{tabular}

Notes:

EU-15 (European Union) countries are:

France, Germany, Italy, Austria, Belgium, Finland, Greece, Ireland, Luxemburg, Netherlands, Portugal, Spain, UK, Denmark, Sweden.

ACC (Acceding into European Union in 2004) countries are: Czech Republic, Estonia, Cyprus, Latvia, Lithuania, Hungary, Malta, Poland, Slovenia, Slovak Republic.

(\#) the population statistic for the USA is for the year 2000.

Sources:

For EU-15 and ACC countries:

For USA:

For Russia:
Labour Force Survey Principal Results 2002, Acceding Countries. Eurostat, European Communities, 2003.

Population: US Census Bureau: the Population profile of the United States: 2000.

Employment and unemployment: Bureau of Labor Statistics: Current Population Survey, 2002.

Goskomstat Rossii, 2002, “Ekonomicheskaya Aktivnost' Naseleniya Rossii”. (In Russian). 


\section{Appendix 1 (Continued)}

Table A1.2. Russian Federation: Distribution of Unemployed by Job Search Methods, \%

\begin{tabular}{|c|c|c|c|c|c|c|c|c|c|c|}
\hline Job Search Methods & 1993 & 1994 & 1995 & 1996 & 1997 & 1998 & 1999 & 2000 & 2001 & 2002 \\
\hline Application to the state employment service & 28.3 & 34.4 & 36.3 & 39.0 & 39.9 & 37.3 & 29.4 & 25.9 & 30.3 & 33.3 \\
\hline Application to a commercial employment service & 3.1 & 3.7 & 3.8 & 4.2 & 2.4 & 2.4 & 1.5 & 2.3 & 3.5 & 5.9 \\
\hline Placing ads in papers, responding to ads & 13.6 & 15.6 & 16.9 & 17.6 & 16.3 & 18.6 & 18.0 & 24.0 & 24.7 & 23.7 \\
\hline Contacting friends, relatives, acquaintances & 36.7 & 37.8 & 38.5 & 37.0 & 55.0 & 57.7 & 54.5 & 58.4 & 59.1 & 59.7 \\
\hline Directly contacting the management/employer & 30.9 & 29.0 & 27.9 & 25.6 & 28.8 & 29.4 & 31.9 & 30.5 & 27.9 & 28.2 \\
\hline Other methods & 14.8 & 13.4 & 16.7 & 15.2 & 16.0 & 16.7 & 11.5 & 14.3 & 11.8 & 13.8 \\
\hline
\end{tabular}

Note: the sum is bigger than $100 \%$ because more than one search method could have been used.

Sources:

For years 1993-2001: Goskomstat Rossii, Ekonomicheskaya Aktivnost' Naseleniya Rossii, 2002, Table 4.10.

For the year 2002: $\quad$ International Monetary Fund. 2003. Russian Federation: Statistical Appendix, Table 13. 
$\underline{\text { Appendix } 2}$

Table A2.1. Relation between Single Job Search Methods and Broad Search Strategies

\begin{tabular}{|c|c|c|c|}
\hline Single Job Search Methods & Frequency of Use & Broad Job Search Strategies & Frequency of Use \\
\hline Advertisements & 42 & & \\
\hline Enterprises directly & 121 & FIRMS & 163 \\
\hline Friends & 197 & & \\
\hline Relatives & 22 & CONTACTS & 219 \\
\hline Private Employment Services & 17 & & \\
\hline State Employment Services & 158 & AGENCIES & 175 \\
\hline Total & 557 & Total & 55 \\
\hline
\end{tabular}


Table A3.1. Summary Statistics for Pooled Data

$\underline{\text { Appendix } 3}$

\begin{tabular}{|c|c|c|c|c|c|}
\hline \multicolumn{2}{|c|}{ Variable } & \multicolumn{2}{|c|}{$\begin{array}{l}\text { Engagement Equation } \\
\qquad N=13286\end{array}$} & \multicolumn{2}{|c|}{$\begin{array}{c}\text { Search Intensity and Search } \\
\text { Method Choice Equations } \\
\qquad N=1310\end{array}$} \\
\hline & & Mean & St.Dev. & Mean & St.Dev. \\
\hline Sex & Female & 0.6344 & 0.4816 & 0.5267 & 0.4995 \\
\hline \multirow[t]{3}{*}{ Age } & Below 25 & 0.2452 & 0.4302 & & \\
\hline & $25-50$ & 0.2076 & 0.4056 & & \\
\hline & Above 50 & 0.5639 & 0.4960 & & \\
\hline \multirow[t]{2}{*}{ Education } & Secondary & 0.3589 & 0.4797 & 0.5641 & 0.4961 \\
\hline & College & 0.0887 & 0.2844 & 0.1313 & 0.3379 \\
\hline \multicolumn{2}{|l|}{ Years of Experience } & & & 16.6126 & 12.4837 \\
\hline Residence & Region 1 & 0.0655 & 0.2474 & 0.1046 & 0.3061 \\
\hline Children & $0-7$ years old & 0.1851 & 0.3884 & 0.2756 & 0.4470 \\
\hline \multicolumn{2}{|l|}{ Wage Arrears } & 0.0466 & 0.2108 & & \\
\hline \multicolumn{2}{|c|}{ Search } & 0.1413 & 0.3483 & 1 & 0 \\
\hline \multicolumn{2}{|c|}{ Number of Single Methods Used (1-6) } & & & 2.2206 & 1.3600 \\
\hline \multirow[t]{4}{*}{ Broad Search Strategies } & AGENCIES & & & 0.1336 & 0.3403 \\
\hline & CONTACTS & & & 0.1672 & 0.3733 \\
\hline & FIRMS & & & 0.1244 & 0.3302 \\
\hline & MULTIPLE & & & 0.5748 & 0.4946 \\
\hline
\end{tabular}

Notes:

Region 1 consists of Metropolitan Areas of Moscow and St. Petersburg.

Secondary education level includes people completed professional courses and professional technical institutions (PTU, FZU) (between 1 and 3 years of studies beyond basic education (11 years).

College education level includes people completed institutes and universities (at least 5 years of studies beyond basic education (11 years)).

Broad Search Strategies are described in the text and in Appendix 2. 
Table A4.1. Variables Used in the Engagement Equation, $\mathrm{N}=\mathbf{1 3 2 8 6}$

\begin{tabular}{|c|c|c|}
\hline Variable & Frequency & Percent \\
\hline \multicolumn{3}{|l|}{ Sex } \\
\hline Female & 8429 & 63.44 \\
\hline Male & 4857 & 36.56 \\
\hline Total & 13286 & 100 \\
\hline \multicolumn{3}{|l|}{ Age } \\
\hline Age $<25$ years old & 3258 & 24.52 \\
\hline Age $25-50$ years old & 2758 & 20.76 \\
\hline Age $>50$ years old & 7270 & 54.72 \\
\hline Total & 13286 & 100 \\
\hline \multicolumn{3}{|l|}{ Education } \\
\hline Secondary Education & 4768 & 35.89 \\
\hline College Education & 1179 & 8.87 \\
\hline \multicolumn{3}{|l|}{ Residence } \\
\hline Residence in Region 1 & 870 & 6.55 \\
\hline \multicolumn{3}{|l|}{ Labor Market Specific } \\
\hline Wage Arrears & 619 & 4.66 \\
\hline \multicolumn{3}{|l|}{ Household Characteristic } \\
\hline Presence of Children 0-7 years old & 2459 & 18.51 \\
\hline
\end{tabular}


Table A5.1. Variables Used in Search Intensity and Search Method Choice Equations, $N=1310$

\begin{tabular}{|c|c|c|}
\hline Variable & Frequency & Percent \\
\hline \multicolumn{3}{|l|}{ Sex } \\
\hline Female & 690 & 52.67 \\
\hline Male & 620 & 47.33 \\
\hline Total & 1310 & 100 \\
\hline Experience & & Range \\
\hline Number of Years Worked & 1097 & $0-54$ \\
\hline \multicolumn{3}{|l|}{$\begin{array}{r}\text { Education } \\
\end{array}$} \\
\hline Secondary Education & 739 & 56.41 \\
\hline College Education & 172 & 13.13 \\
\hline \multicolumn{3}{|l|}{ Residence } \\
\hline Residence in Region 1 & 137 & 10.46 \\
\hline \multicolumn{3}{|l|}{ Household Characteristic } \\
\hline Presence of Children 0-7 yeasr old & 361 & 27.56 \\
\hline \multicolumn{3}{|l|}{ Number of Methods Used } \\
\hline 1 & 558 & 42.60 \\
\hline 2 & 288 & 21.98 \\
\hline 3 & 211 & 16.11 \\
\hline 4 & 150 & 11.45 \\
\hline 5 & 76 & 5.80 \\
\hline 6 & 27 & 2.06 \\
\hline Total & 1310 & 100 \\
\hline \multicolumn{3}{|l|}{ Broad Job Search Strategies } \\
\hline AGENCIES & 175 & 13.36 \\
\hline FIRMS & 163 & 12.44 \\
\hline CONTACTS & 219 & 16.72 \\
\hline MULTIPLE & 753 & 57.48 \\
\hline Total & 1310 & 100 \\
\hline
\end{tabular}




\section{DAVIDSON INSTITUTE WORKING PAPER SERIES - Most Recent Papers}

The entire Working Paper Series may be downloaded free of charge at: www.wdi.bus.umich.edu

CURRENT AS OF 11/14/03

\begin{tabular}{|c|c|c|}
\hline Publication & Authors & Date \\
\hline No. 629: Job Search Behavior of Unemployed in Russia & Natalia Smirnova & Nov. 2003 \\
\hline $\begin{array}{l}\text { No. 628: How has Economic Restructuring Affected China's Urban } \\
\text { Workers? }\end{array}$ & John Giles, Albert Park, Feng Cai & Oct. 2003 \\
\hline No. 627: The Life Cycle of Government Ownership & Jiahua Che & Oct. 2003 \\
\hline $\begin{array}{l}\text { No. 626: Blocked Transition And Post-Socialist Transformation: Siberia } \\
\text { in the Nineties }\end{array}$ & Silvano Bolcic & Oct. 2003 \\
\hline $\begin{array}{l}\text { No. 625: Generalizing the Causal Effect of Fertility on Female Labor } \\
\text { Supply }\end{array}$ & $\begin{array}{l}\text { Guillermo Cruces and Sebastian } \\
\text { Galiani }\end{array}$ & Oct. 2003 \\
\hline $\begin{array}{l}\text { No. 624: The Allocation and Monitoring Role of Capital Markets: } \\
\text { Theory and International Evidence }\end{array}$ & Solomon Tadesse & Oct. 2003 \\
\hline No. 623: Firm-Specific Variation and Openness in Emerging Markets & $\begin{array}{l}\text { Kan Li, Randall Morck, Fan Yang } \\
\text { and Bernard Yeung }\end{array}$ & Oct. 2003 \\
\hline $\begin{array}{l}\text { No. 622: Exchange Rate Regimes and Volatility: Comparison of the } \\
\text { Snake and Visegrad }\end{array}$ & $\begin{array}{l}\text { Juraj Valachy and Evžen } \\
\text { Kočenda }\end{array}$ & Oct. 2003 \\
\hline $\begin{array}{l}\text { No. 621: Do Market Pressures Induce Economic Efficiency?: The Case } \\
\text { of Slovenian Manufacturing, 1994-2001 }\end{array}$ & $\begin{array}{l}\text { Peter F. Orazem and Milan } \\
\text { Vodopivec }\end{array}$ & Oct. 2003 \\
\hline $\begin{array}{l}\text { No. 620: Compensating Differentials in Emerging Labor and Housing } \\
\text { Markets: Estimates of Quality of Life in Russian Cities }\end{array}$ & $\begin{array}{l}\text { Mark C. Berger, Glenn C. } \\
\text { Blomquist and Klara Sabirianova } \\
\text { Peter }\end{array}$ & Oct. 2003 \\
\hline $\begin{array}{l}\text { No. 619: Are Foreign Banks Bad for Development Even If They Are } \\
\text { Efficient? Evidence from the Indian Banking Sector }\end{array}$ & $\begin{array}{l}\text { Sumon Bhaumik and Jenifer } \\
\text { Piesse }\end{array}$ & Oct. 2003 \\
\hline No. 618: The Echo of Job Displacement & $\begin{array}{l}\text { Marcus Eliason and Donald } \\
\text { Storrie }\end{array}$ & Oct. 2003 \\
\hline No. 617: Deposit Insurance During Accession EU Accession & $\begin{array}{l}\text { Nikolay Nenovsky and Kalina } \\
\text { Dimitrova }\end{array}$ & Oct. 2003 \\
\hline $\begin{array}{l}\text { No. 616: Skill-Biased Transition: The Role of Markets, Institutions, and } \\
\text { Technological Change }\end{array}$ & Klara Sabirianova Peter & Oct. 2003 \\
\hline $\begin{array}{l}\text { No. 615: Initial Conditions, Institutional Dynamics and Economic } \\
\text { Performance: Evidence from the American States }\end{array}$ & Daniel Berkowitz and Karen Clay & Sept. 2003 \\
\hline $\begin{array}{l}\text { No. 614: Labor Market Dynamics and Wage Losses of Displaced } \\
\text { Workers in France and the United States }\end{array}$ & Arnaud Lefranc & Sept. 2003 \\
\hline No. 613: Firm Size Distribution and EPL in Italy & $\begin{array}{l}\text { Fabiano Schivardi and Roberto } \\
\text { Torrini }\end{array}$ & Sept. 2003 \\
\hline $\begin{array}{l}\text { No. 612: The Effect of Employee Involvment on Firm Performance: } \\
\text { Evidence from an Econometric Case Study }\end{array}$ & Derek C. Jones and Takao Kato & Sept. 2003 \\
\hline No. 611: Working Inflow, Outflow, and Churning & $\begin{array}{l}\text { Pekka Ilmakunnas and Mika } \\
\text { Maliranta }\end{array}$ & Sept. 2003 \\
\hline $\begin{array}{l}\text { No. 610: Signaling in The Labor Market: New Evidence On Layoffs, } \\
\text { and Plant Closings }\end{array}$ & Nuria Rodriguez-Planas & Sept. 2003 \\
\hline $\begin{array}{l}\text { No. 609: Job Flows and Establishment Characteristics: Variations } \\
\text { Across U.S. Metropolitan Areas }\end{array}$ & R. Jason Faberman & Sept. 2003 \\
\hline No. 608: Dowry and Intrahousehold Bargaining: Evidence from China & Philip H. Brown & Sept. 2003 \\
\hline $\begin{array}{l}\text { No. 607: Policy Regime Change and Corporate Credit in Bulgaria: } \\
\text { Asymmetric Supply and Demand Responses }\end{array}$ & $\begin{array}{l}\text { Rumen Dobrinsky and Nikola } \\
\text { Markov }\end{array}$ & Sept. 2003 \\
\hline $\begin{array}{l}\text { No. 606: Corporate Performance and Market Structure During } \\
\text { Transition in Hungary }\end{array}$ & László Halpern and Gábor Kõrösi & Aug. 2003 \\
\hline $\begin{array}{l}\text { No. 605: Culture Rules: The Foundations of the Rule of Law and Other } \\
\text { Norms of Governance }\end{array}$ & $\begin{array}{l}\text { Amir N. Licht, Chanan } \\
\text { Goldschmidt, and Shalom H. } \\
\text { Schwartz }\end{array}$ & Aug. 2003 \\
\hline No. 604: Institutional Subversion: Evidence from Russian Regions & $\begin{array}{l}\text { Irina Slinko, Evgeny Yakovlev, } \\
\text { and Ekaterina Zhuravskaya }\end{array}$ & Aug. 2003 \\
\hline
\end{tabular}

